\title{
Development of Onion Powder by using Egg Albumin as a Foaming Agent by Foam-Mat Drying Process
}

\author{
Muhammad Farooq ${ }^{1 *}$, M. Javed Iqbal ${ }^{2}$, Rizwan Shukat ${ }^{2}$, Qayyum Shehzad ${ }^{3}$, Shabir Ahmed ${ }^{4}$, Elham \\ Azadfar ${ }^{5}$, Abdul Saboor ${ }^{6}$, Ibrar Ahmad ${ }^{7}$, Iftikhar Ahmed Solangi ${ }^{1}$, Kaleem Kakar ${ }^{8}$, Shoaib Khan ${ }^{9}$ and \\ Wang Yunyang ${ }^{1}$
}

${ }^{1}$ College of Food Science and Engineering, Northwest A and F University, Yangling, Shaanxi 712100, PR China; ${ }^{2}$ Department of Food Technology National Institute of Food Science and Technology, University, of Agriculture Faisalabad, Pakistan; ${ }^{3}$ National Engineering Laboratory for Agri-Product Quality Traceability Beijing Technology and Business University Beijing China; ${ }^{4}$ Assistant Director Food, Zhob Baluchistan, Pakistan; ${ }^{5}$ Young Researchers, and Elites Club, Sabzevar Branch, Islamic Azad University, Sabzevar, Iran; ${ }^{6}$ School of Food Science and Biological Engineering, Jiangsu University, China; ${ }^{7}$ Soil and Environmental Sciences, The University of Agriculture Peshawar, Khyber Pakhtunkbwa, Pakistan; ${ }^{8}$ Department of Horticulture, Sindh Agriculture University, Tando Jam, Pakistan; ${ }^{9}$ Department of Horticulture, The University of Agriculture Peshawar, Khyber Pakbtunkbwa, Pakistan.

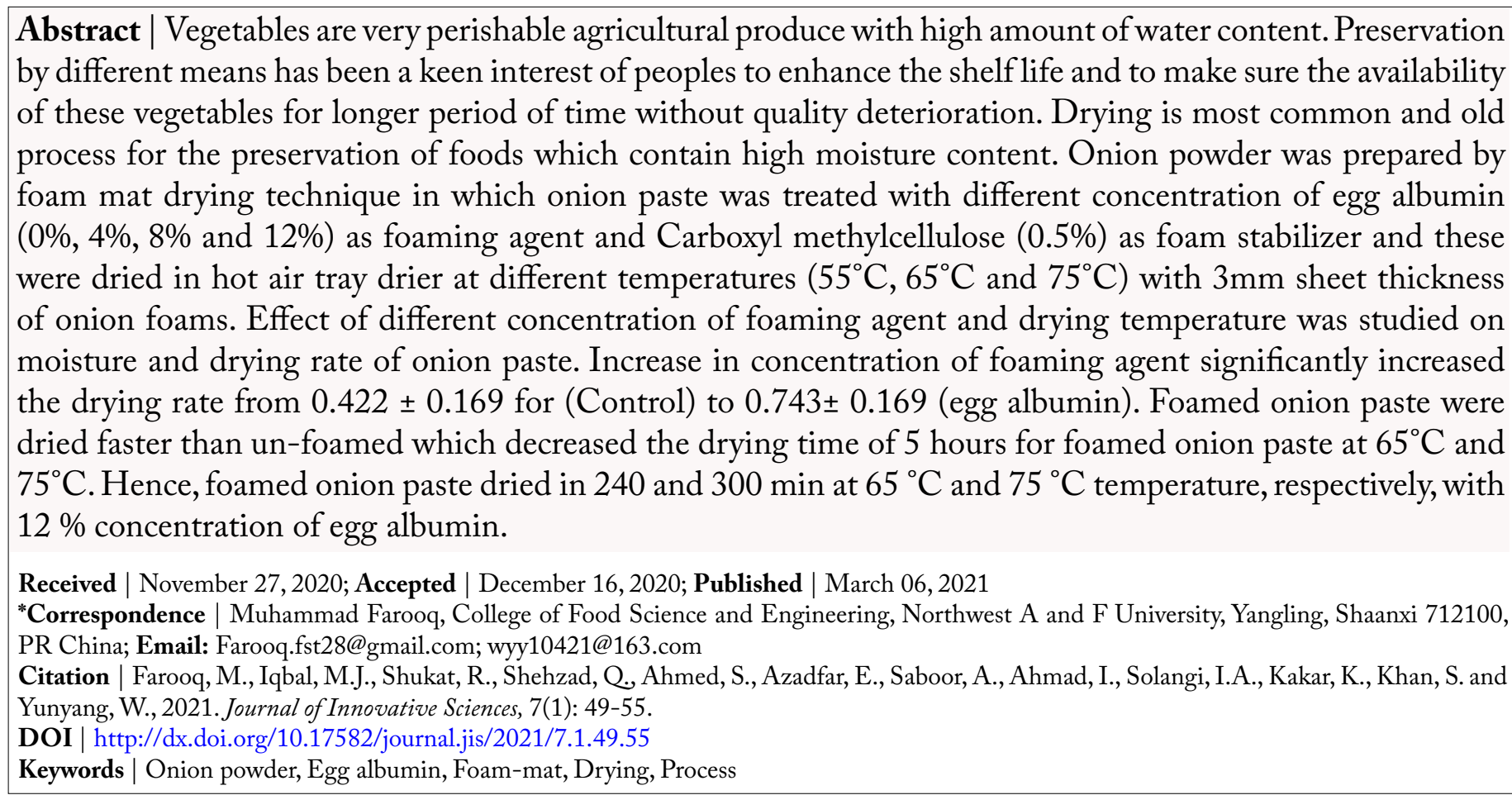

\section{Introduction}

$\mathrm{V}$ egetables are one of the important part of our diet. Vegetables provide nutrient to support our daily life activities. Besides being a source of energy vegetables have many bioactive compound with potential to prevent human diseases. It is considered that those people who make the vegetables a chief part in their daily diet are less likely to be effected by any chronic disease. Human "well-being" is highly associated with diet which we consume. Now a day's lack of physical activity and high energy diet 
intake is resulted into several health complications like as diabetes mellitus, obesity and cardiovascular diseases. Vegetables have polyphenols and other bioactive compounds for the prevention of these chronic diseases. Vegetables are an important source of dietary fibers, although this component of vegetables is not well defined but fiber matrix of vegetables helps to transport bioactive compounds from human gut to colon. Dietary fiber of vegetables helps to lower the cholesterol level in blood and reduces cardiovascular diseases. Fibers are considered very important for bowel to function properly (Asif, 2011). Recommended amount of vegetables is $200 \mathrm{~g}$ per day for a person (Keatinge et al., 2011), but now a days total vegetable consumption amount is very less in many countries. In Pakistan daily vegetables consumption (per person per day) is about $100 \mathrm{~g}$ which is very lower than recommended amount of 200g (Khokhar, 2012).

Onion (Allium cepa) crop is grown and commercially available throughout the world. It is used as such in raw form as salad, spices and in medicines. This vegetable is rich in carbohydrates, proteins, Vitamin C and minerals like calcium and phosphorous (Mishra et al., 2014). it is very oldest cultivated crop in history of mankind and Ancient Egyptian has been using onion in their medicinal formulas for the cure of many diseases. Onion is cultivated about on area of 4.4 million hectares with 85.8 million tones production in all over the world (Agnieszka et al., 2017). In the Pakistan onion crop is grown on an area of 147.6 thousand hectares with total production of 1939.6 thousand tons of which 41\% produced by Sindh, 29\% by Baluchistan and 20\% by Punjab (Khokhar, 2014).

Onion processing and preservation by appropriate method with minimum quality changes has been a great interest of researchers. All have been working to increase the storage stability of onions and others vegetables to make their availability for a long period with high quality. High moisture content of onion renders it susceptible to microbial attack and different kind of chemical changes. Due to lack of proper processing and storage techniques a large portion of food material is lost. It is estimated that about Rs. 500 million worth of agriculture food is wasted every year (Cardoen et al., 2015). Drying is oldest process in preservation of food materials, in which heat is applied to evaporate the water and make it unavailable for different microorganisms and enzymes, which ultimately result in increase in the shelf life of products (Chieh, 2006). Microbial progression depends upon the moisture content of vegetables and storage conditions, different type of microbes have different growth rate depending on conditions by which vegetables are processed, preserved and stored. Dehydration make the vegetables safe to microbial spoilage by decreasing the water activity and increasing the shelf life longer than fresh vegetables.

For the drying of food materials there are many different methods such as sun drying, freeze drying, microwave drying, oven drying, infrared drying and vacuum drying etc. Vegetables have many compounds such as phenolic and vitamins, which are very sensitive to high temperature that's why selection of the drying technique depends upon final quality of end product, cost and many others factors which should be kept in mind during selection of appropriate drying technique.

A new technique name as foam-mat drying which is highly suitable for those foods which are sticky, very viscous and sensitive to high temperature, variety of food material can be dried by this technique with minimum quality changes (Kadam et al., 2010). This technique for the drying was developed by Morgan in USA in 1959 and many researchers have reported that this technique is very cost effective and suitable for drying of those products which are very heat sensitive and difficult to dry. Different food pastes and juices are mixed with suitable foaming agent to convert them into stable foams and these foams are subjected to hot air treatment and dried. Application of foaming agent treatment hence increases the total surface area, so product dry faster with less quality changes.

In our present work egg albumin is used to study the drying characteristics of onion paste to develop onion powder. Egg albumin is added in different concentration to develop foams in onion paste and then these foams are dried at different temperatures to study the effect of foaming agent treatments on drying characteristics of onion paste.

\section{Materials and Methods}

\subsection{Procurement and preparation of raw material}

Onions were purchased from a local vegetable market in Faisalabad, sorted for good quality without bruises, 
cuts and microbial attacks. Which were peeled off, washed and grinded with grinder and converted into paste in fruits and vegetable lab at National Institute of Food Science and Technology, University of Agriculture Faisalabad. Eggs weighing from 74.71g to $64.59 \mathrm{~g}$ were purchased from student market of University of Agriculture Faisalabad, Pakistan to extract fresh egg albumin which contains about 38$50 \mathrm{~g}$ of egg albumin and that egg albumin extract was homogenized and used as a foaming agent in different concentration.

\subsection{Development of onion foams by egg albumin}

Onion paste weighing $200 \mathrm{~g}$ was taken for each experiment and treated with different concentration of egg albumin (0\%, 4\%, 8\% and 12\%) as foaming agent. Carboxyl methyl cellulose $(0.5 \%)$ was used as a foam stabilizer. Onion paste, foaming agent and foam stabilizer in determined concentration were mixed in a $1000 \mathrm{ml}$ beaker and beating was done for 3 minutes to increase surface area of onion paste by developing stable foams with incorporation of maximum amount of air in onion paste by using a small scale hand beater used in kitchen for beating of eggs.

\subsection{Foam spreading in trays and drying}

Foams of Onion paste subjected to different concentration of egg albumin (0\%, 4\%, 8\% and 12\%) as foaming agent were spread to $3 \mathrm{~mm}$ sheet thickness on aluminum foils and placed in stainless steel trays. Commercially available hot air tray dryer (Model\# R-5A, Serial\# 10-213, Commercial dehydrator systems, Inc., Germany) was used for drying experiment in fruits and vegetable lab at National institute of food science and technology, University of Agriculture Faisalabad, Punjab, Pakistan. Drying was carried out in 3 batches, first batch was dried at $55{ }^{\circ} \mathrm{C}$ comprising on four samples, one (Controlled) not treated with any foaming agent while three others which were treated with $4 \%, 8 \%$ and $12 \%$ concentration of egg albumin respectively. All the four samples were prepared again with same above mentioned concentrations of foaming agent and dried at $65 \mathrm{C}$ and $75 \mathrm{C}$. During drying experiment after each 60 minutes weight of all samples were recorded and when constant weight was appeared, all the samples from the dryer were removed and placed in desiccator.

\subsection{Milling and storage of powder}

All the samples were removed from the desiccator and grounded in a grinder to develop free flowing powders.
All the samples were stored at room temperature in polythene bags.

\subsection{Moisture loss and drying rate}

During the drying experiments of onion foams developed by different concentration of egg albumin as foaming agent at different drying temperatures. Weight of each sample was recoded after an hour by a weighing balance, which was used to determine the decrease in moisture content of onion foams during drying process. Initial moisture content in onion foams were calculated by AOAC (2017) standard method of moisture calculation. Final moisture content of onion powders were also measured. By using the data of decrease in moisture of different samples drying rate was calculated by using equation.

\section{$\Delta \mathrm{X} / \Delta \mathrm{t} 1$}

\subsection{Drying curves}

Drying curves for moisture loss and drying rate was plotted by using the data of moisture loss $\mathrm{X}$ from onion foams and drying rate $\Delta \mathrm{X} / \Delta \mathrm{t}$ verses time. Drying curves give information to know about exact drying time where these onion foams are dried. By these drying curves we can have idea about the best concentration of egg albumin and temperature where sample dried in minimum time.

\subsection{Statistical Analysis}

The data of each parameter was analyzed by two-way ANOVA statistical analysis to determine the level of significance and comparison of means by Tuckey test according to the method defined by Montgomey.

\section{Results and Discussion}

Onion powder was produced by using egg albumin in different concentration levels. Data for moisture loss for onion powders developed by different concentration levels of egg albumin as foaming agent for which values are given in Tables 1, 2 and 3 which were used to draw drying curves for moisture loss which can be seen in Figures 1, 2 and 3 for drying at $55^{\circ} \mathrm{C}, 65^{\circ} \mathrm{C}$ and $75^{\circ} \mathrm{C}$. From the available data it was observed that moisture content decreased with time. Analysis of variance (ANOVA) showed highly significant effect of foaming agent and temperature $(\mathrm{P}<0.01)$. Foaming treatment resulted in faster drying as compare to non-foamed onion paste drying. Drying was fast for all experiments in which foaming agent was used. 
Table 1: Moisture loss from onion paste drying at $55^{\circ} \mathrm{C}$ temperature using different concentration egg albumin as foaming agent.

Drying of onion paste at $55^{\circ} \mathrm{C}$ temperature

\begin{tabular}{llllll}
\hline $\begin{array}{l}\text { Sr. } \\
\text { No. }\end{array}$ & $\begin{array}{l}\text { Time, } \\
\text { t(min) }\end{array}$ & \multicolumn{4}{l}{ Moisture content, $\mathbf{X}$ ( g moisture/g dry solid) } \\
\hline Treatments & $\begin{array}{l}\mathbf{T}_{\mathbf{0}} \\
\text { (Control) }\end{array}$ & $\begin{array}{l}\mathbf{T}_{\mathbf{1}} \\
\text { (EA=4\%) }\end{array}$ & $\begin{array}{l}\mathbf{T}_{\mathbf{2}} \\
\text { (EA=8\%) }\end{array}$ & $\begin{array}{l}\mathbf{T}_{\mathbf{3}} \\
(\mathbf{E A = 1 2 \% )}\end{array}$ \\
\hline 1 & 0 & 183 & 183 & 183 & 183 \\
2 & 60 & 154 & 128.1 & 125 & 118 \\
3 & 120 & 127 & 82 & 75 & 62 \\
4 & 180 & 105.3 & 59 & 52 & 28.5 \\
5 & 240 & 84 & 41.4 & 38 & 7 \\
6 & 300 & 64.7 & 25.4 & 24 & 0 \\
7 & 360 & 48.4 & 9.4 & 10 & \\
8 & 420 & 32 & 0 & 0 & \\
9 & 480 & 18.5 & & & \\
10 & 540 & 9 & & & \\
11 & 600 & 0 & & &
\end{tabular}

Table 2: Moisture loss from onion paste drying at $65^{\circ} \mathrm{C}$ temperature using different concentration egg albumin as foaming agent.

\begin{tabular}{|c|c|c|c|c|c|}
\hline \multicolumn{6}{|c|}{ Drying of onion paste at $65^{\circ} \mathrm{C}$ temperature } \\
\hline \multicolumn{2}{|c|}{$\begin{array}{l}\text { Sr. Time, } \\
\text { No. } t \text { (min) }\end{array}$} & \multicolumn{4}{|c|}{ Moisture content, $\mathrm{X}$ ( $\mathrm{g}$ moisture/g dry solid) } \\
\hline & itments & $\begin{array}{l}T_{0} \\
\text { (Control) }\end{array}$ & $\begin{array}{l}\mathrm{T}_{1} \\
(\mathrm{EA}=4 \%)\end{array}$ & $\begin{array}{l}\mathrm{T}_{2} \\
(\mathrm{EA}=8 \%)\end{array}$ & $\begin{array}{l}\mathrm{T}_{3} \\
(\mathrm{EA}=12 \%)\end{array}$ \\
\hline 1 & 0 & 183 & 183 & 183 & 183 \\
\hline 2 & 60 & 143.2 & 115 & 114 & 103 \\
\hline 3 & 120 & 109 & 73.2 & 70.45 & 53 \\
\hline 4 & 180 & 78 & 46.8 & 37 & 20 \\
\hline 5 & 240 & 53 & 23.4 & 7 & 0 \\
\hline 6 & 300 & 31 & 3.4 & 0 & \\
\hline 7 & 360 & 11 & 0 & & \\
\hline 8 & 420 & 0 & & & \\
\hline
\end{tabular}

Table 3: Moisture loss from onion paste drying at $75^{\circ} \mathrm{C}$ temperature using different concentration egg albumin as foaming agent.

\begin{tabular}{|c|c|c|c|c|c|}
\hline \multicolumn{6}{|c|}{ Drying of onion paste at $75^{\circ} \mathrm{C}$ temperature } \\
\hline \multicolumn{2}{|c|}{$\begin{array}{l}\text { Sr. Time, } \\
\text { No. } t(\min )\end{array}$} & \multicolumn{4}{|c|}{ Moisture loss, X (g moisture/g dry solid) } \\
\hline & atments & $\begin{array}{l}\mathrm{T}_{0} \\
\text { (Control) }\end{array}$ & $\begin{array}{l}\mathrm{T}_{1} \\
(\mathrm{EA}=4 \%)\end{array}$ & $\begin{array}{l}\mathrm{T}_{2} \\
(\mathrm{EA}=8 \%)\end{array}$ & $\begin{array}{l}\mathrm{T}_{3} \\
(\mathrm{EA}=12 \%)\end{array}$ \\
\hline 1 & 0 & 183 & 183 & 183 & 183 \\
\hline 2 & 60 & 140.3 & 127.5 & 115.5 & 113 \\
\hline 3 & 120 & 113 & 88 & 73 & 67 \\
\hline 4 & 180 & 88 & 58.5 & 40 & 32 \\
\hline 5 & 240 & 67 & 33 & 17 & 8 \\
\hline 6 & 300 & 46 & 7.5 & 0 & 0 \\
\hline 7 & 360 & 26 & 0 & & \\
\hline 8 & 420 & 8 & & & \\
\hline 9 & 480 & 0 & & & \\
\hline
\end{tabular}

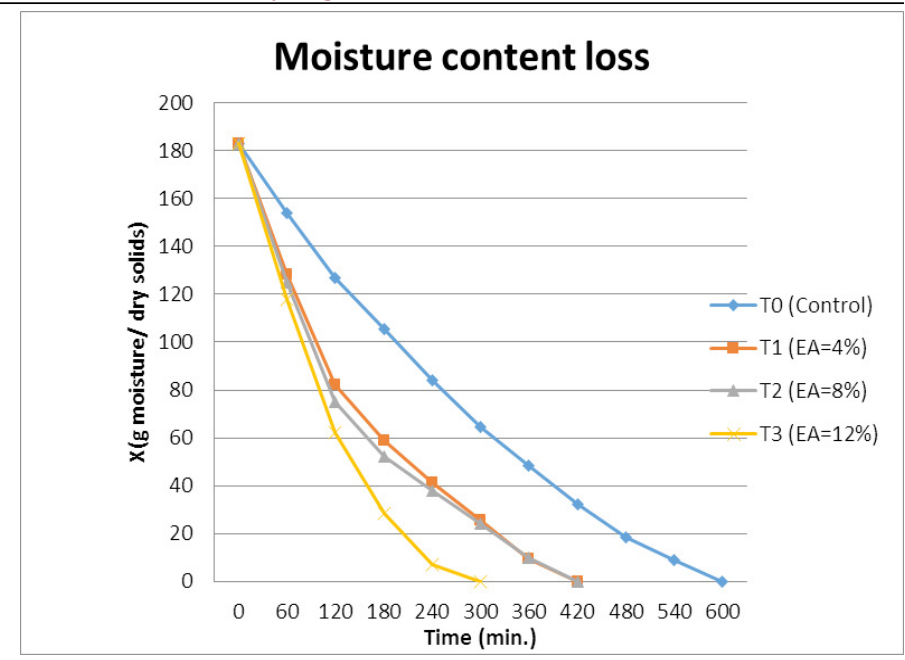

Figure 1: Effect of egg albumin concentration level on moisture during foam mat drying of onion paste at $55^{\circ} \mathrm{C}$.

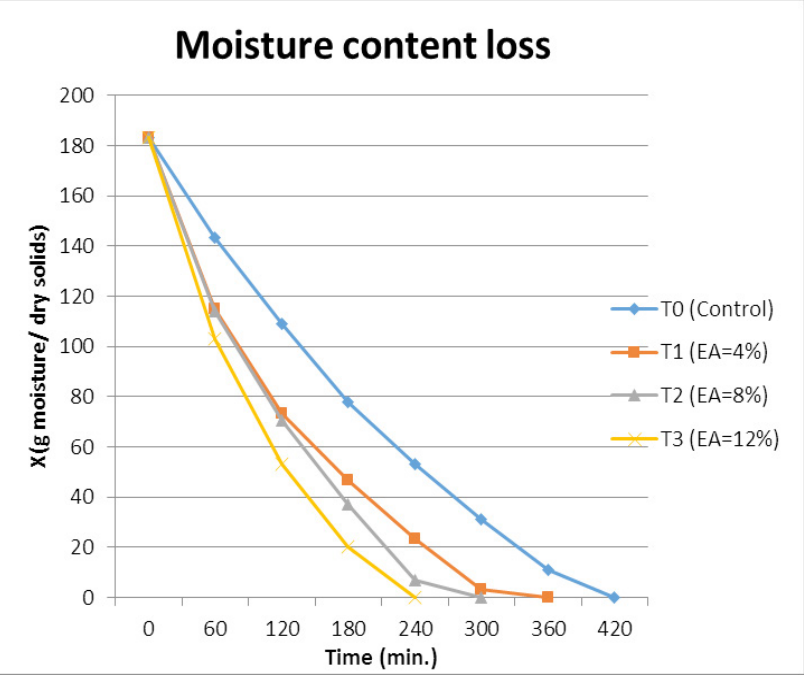

Figure 2: Effect of egg albumin concentration level on moisture during foam mat drying of onion paste at $65^{\circ} \mathrm{C}$.

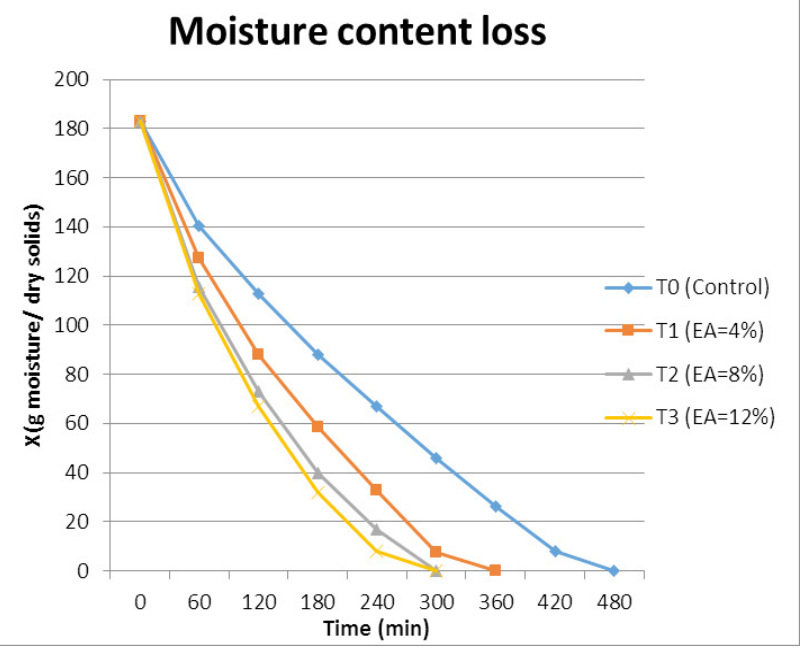

Figure 3: Effect of egg albumin concentration level on moisture during foam mat drying of onion paste at $75^{\circ} \mathrm{C}$. 
Initially $200 \mathrm{~g}$ onion paste sample was taken which contained $184 \mathrm{~g}$ of moisture content and dried to achieve constant weight in try drier at $55^{\circ} \mathrm{C}, 65^{\circ} \mathrm{C}$ and $75^{\circ} \mathrm{C}$. At $55^{\circ} \mathrm{C}$ onion paste without foaming agent (Control) take 10 hours to dry while onion pastes subjected to different concentration of egg albumin dried faster and saved 5 hours which can be seen in Table 1. As foaming treatment increases the surface area for drying which is resulted in better and faster removal of moisture content from onion paste. While removal of moisture from un-foamed onion paste was slow because of dense structure which resulted in slow moisture reduction. Increase in concentration of foaming agent resulted in faster drying. Fastest drying of onion paste at $55^{\circ} \mathrm{C}$ was observed for $12 \%$ concentration of egg albumin as foaming agent. As indicated in Figure 4 increase in temperature resulted in significantly drop in moisture content of onion powders. Dehghannya (2019); Kadam et al. (2011) reported similar results. In this research descending trend in moisture content of onion powders were observed with increase in temperature for which values are given in Tables 1, 2 and 3 .

Table 4: Drying rate of onion paste at $55^{\circ} \mathrm{C}$ using different concentration of egg albumin as foaming agent.

\begin{tabular}{|c|c|c|c|c|c|}
\hline \multicolumn{6}{|c|}{$\begin{array}{l}\text { Sr. Time Drying rate at } 55^{\circ} \mathrm{C}, \mathrm{N}(\mathrm{g} / \mathrm{cm} 2 \mathrm{~min}) \\
\text { No }\end{array}$} \\
\hline \multicolumn{2}{|c|}{$\begin{array}{l}\text { Treat- } \\
\text { ments }\end{array}$} & \multirow{2}{*}{$\begin{array}{l}\mathbf{T}_{\mathbf{0}} \\
\text { (Control) }\end{array}$} & \multirow{2}{*}{$\begin{array}{l}\mathrm{T}_{1} \\
(\mathrm{EA}=\mathbf{4 \%}) \\
0\end{array}$} & \multirow{2}{*}{$\begin{array}{l}\mathrm{T}_{\mathbf{2}} \\
\mathbf{( E A = 8 \% )} \\
0\end{array}$} & \multirow{2}{*}{$\begin{array}{l}\mathrm{T}_{3} \\
(\mathrm{EA}=12 \%) \\
0\end{array}$} \\
\hline 1 & 0 & & & & \\
\hline 2 & 60 & $0.453 \pm 0.02$ & $0.903 \pm 0.015$ & $0.963 \pm 0.014$ & $1.026 \pm 0.047$ \\
\hline 3 & 120 & $0.423 \pm 0.02$ & $0.710 \pm 0.052$ & $0.830 \pm 0.020$ & $0.910 \pm 0.017$ \\
\hline 4 & 180 & $0.350 \pm 0.01$ & $0.373 \pm 0.020$ & $0.356 \pm 0.021$ & $0.570 \pm 0.017$ \\
\hline 5 & 240 & $0.346 \pm 0.02$ & $0.270 \pm 0.010$ & $0.230 \pm 0.020$ & $0.343 \pm 0.015$ \\
\hline 6 & 300 & $0.330 \pm 0.01$ & $0.276 \pm 0.011$ & $0.206 \pm 0.021$ & $0.176 \pm 0.012$ \\
\hline 7 & 360 & $0.286 \pm 0.01$ & $0.270 \pm 0.010$ & $0.216 \pm 0.023$ & 0 \\
\hline 8 & 420 & $0.243 \pm 0.02$ & $0.170 \pm 0.010$ & $0.143 \pm 0.023$ & \\
\hline 9 & 480 & $0.193 \pm 0.0$ & 0 & 0 & \\
\hline 10 & 540 & $0.130 \pm 0.0$ & & & \\
\hline 11 & 600 & $0.156 \pm 0.0$ & & & \\
\hline 12 & 660 & 0 & & & \\
\hline
\end{tabular}

Drying rate was calculated and used to draw drying rate curves for which data is given in Tables 4, 5 and 6. Drying rate for the onion powder at $55^{\circ} \mathrm{C}, 65^{\circ} \mathrm{C}$ and $75^{\circ} \mathrm{C}$ were evaluated by drying curves shown in Figures 5, 6 and 7 for drying at $55^{\circ} \mathrm{C}, 65^{\circ} \mathrm{C}$ and $75^{\circ} \mathrm{C}$. Drying curves were drawing with the data on the rate of drying versus time. Falling rate period was observed with passage of time because in start of the drying onion paste contains very high water content while with the passage of time during drying water content decreased and it became hard to remove moisture from inside of the sample. Hence, drying rate decreases with time. Mean values for drying rate of onion paste dried at $55^{\circ} \mathrm{C}, 65^{\circ} \mathrm{C}$ and $75^{\circ} \mathrm{C}$ by using different concentration (4\%, $8 \%$ and $12 \%)$ egg albumin as foaming agents are given in Table 4. From the data it is shown that highest drying rate for egg albumin was $0.743 \pm 0.169$ at $65^{\circ} \mathrm{C}$ with $12 \%$ concentration.

Table 5: Drying rate of onion paste at $65^{\circ} \mathrm{C}$ using different concentration of egg albumin as foaming agent.

\begin{tabular}{|c|c|c|c|c|c|}
\hline \multicolumn{2}{|c|}{$\begin{array}{l}\text { Treat- } \\
\text { ments }\end{array}$} & \multirow{2}{*}{$\begin{array}{l}\mathbf{T}_{\mathbf{0}} \\
\text { (Control) } \\
0\end{array}$} & \multirow{2}{*}{$\begin{array}{l}\mathrm{T}_{1} \\
(\mathrm{EA}=\mathbf{4 \%}) \\
0\end{array}$} & \multirow{2}{*}{$\begin{array}{l}\mathrm{T}_{2} \\
(\mathrm{EA}=\mathbf{8 \%}) \\
0\end{array}$} & \multirow{2}{*}{$\begin{array}{l}\mathrm{T}_{3} \\
(\mathrm{EA}=12 \%) \\
0\end{array}$} \\
\hline 1 & 0 & & & & \\
\hline 2 & 60 & $0.650 \pm 0.010$ & $1.100 \pm 0.026$ & $1.146 \pm 0.005$ & $1.296 \pm 0.030$ \\
\hline 3 & 120 & $0.570 \pm 0.010$ & $0.686 \pm 0.015$ & $0.696 \pm 0.028$ & $0.806 \pm 0.020$ \\
\hline 4 & 180 & $0.503 \pm 0.015$ & $0.480 \pm 0.036$ & $0.563 \pm 0.015$ & $0.566 \pm 0.020$ \\
\hline 5 & 240 & $0.423 \pm 0.050$ & $0.416 \pm 0.037$ & $0.490 \pm 0.010$ & $0.303 \pm 0.023$ \\
\hline 6 & 300 & $0.346 \pm 0.025$ & $0.323 \pm 0.011$ & $0.146 \pm 0.025$ & 0 \\
\hline 7 & 360 & $0.306 \pm 0.020$ & 0 & 0 & \\
\hline 8 & 420 & $0.153 \pm 0.025$ & & & \\
\hline 9 & 480 & 0 & & & \\
\hline
\end{tabular}

Table 6: Drying rate of onion paste at $75^{\circ} \mathrm{C}$ using different concentration of egg albumin as foaming agent.

\begin{tabular}{|c|c|c|c|c|c|}
\hline \multicolumn{2}{|c|}{$\begin{array}{l}\text { Sr. Time } \\
\text { No. }\end{array}$} & \multicolumn{4}{|c|}{ Drying rate at $75^{\circ} \mathrm{C}, \mathrm{N}\left(\mathrm{g} / \mathrm{cm}^{2} \mathrm{~min}\right)$} \\
\hline \multicolumn{2}{|c|}{$\begin{array}{l}\text { Treat- } \\
\text { ments }\end{array}$} & \multirow{2}{*}{$\begin{array}{l}T_{0} \\
\text { (Control) }\end{array}$} & \multirow{2}{*}{$\begin{array}{l}\mathrm{T}_{1} \\
(\mathrm{EA}=4 \%) \\
0\end{array}$} & \multirow{2}{*}{$\begin{array}{l}\mathrm{T}_{2} \\
(\mathrm{EA}=\mathbf{8 \%}) \\
0\end{array}$} & \multirow{2}{*}{$\begin{array}{l}\mathrm{T}_{\mathbf{3}} \\
\mathbf{( \mathrm { EA } = 1 2 \% )} \\
0\end{array}$} \\
\hline 1 & 0 & & & & \\
\hline 2 & 60 & $0.700 \pm 0.010$ & $0.923 \pm 0.011$ & $1.140 \pm 0.010$ & $1.150 \pm 0.020$ \\
\hline 3 & 120 & $0.453 \pm 0.011$ & $0.656 \pm 0.015$ & $0.690 \pm$ & $0.760 \pm 0.010$ \\
\hline 4 & 180 & $0.436 \pm 0.015$ & $0.496 \pm 0.011$ & $0.560 \pm 0.017$ & $0.576 \pm 0.015$ \\
\hline 5 & 240 & $0.340 \pm 0.017$ & $0.430 \pm 0.030$ & $0.350 \pm 0.030$ & $0.403 \pm 0.015$ \\
\hline 6 & 300 & $0.333 \pm 0.015$ & $0.423 \pm 0.011$ & $0.260 \pm 0.020$ & $0.113 \pm 0.020$ \\
\hline 7 & 360 & $0.296 \pm 0.012$ & $0.150 \pm 0.020$ & 0 & 0 \\
\hline 8 & 420 & $0.136 \pm 0.011$ & 0 & & \\
\hline 9 & 480 & 0 & & & \\
\hline
\end{tabular}


Table 7: Mean drying rate of onion powder dried at different temperatures $\left(55^{\circ} \mathrm{C}, 65^{\circ} \mathrm{C}\right.$ and $\left.75^{\circ} \mathrm{C}\right)$ using different concentration of egg albumin as foaming agent.

\begin{tabular}{llllll}
\hline \multicolumn{5}{c}{ Mean drying rate } \\
\hline Sr. No & Temperature & $\mathbf{T}_{\mathbf{0}}$ (Control) & $\mathbf{T}_{\mathbf{1}}(\mathbf{E A = 4 \% )}$ & $\mathbf{T}_{\mathbf{2}}(\mathbf{E A}=\mathbf{8 \%})$ & $\mathbf{T}_{\mathbf{3}} \mathbf{( E A = 1 2 \% )}$ \\
\hline 1 & $55^{\circ} \mathrm{C}$ & $0.291 \pm 0.109$ & $0.425 \pm 0.273$ & $0.421 \pm 0.273$ & $0.605 \pm 0.273$ \\
2 & $65^{\circ} \mathrm{C}$ & $0.422 \pm 0.169$ & $0.601 \pm 0.169$ & $0.608 \pm 0.169$ & $0.743 \pm 0.169$ \\
3 & $75^{\circ} \mathrm{C}$ & $0.385 \pm 0.174$ & $0.513 \pm 0.174$ & $0.600 \pm 0.174$ & $0.600 \pm 0.174$ \\
4 & Means & $0.366 \pm 0.068^{\mathrm{d}}$ & $0.513 \pm 0.088^{\mathrm{bc}}$ & $0.543 \pm 0.106^{\mathrm{bc}}$ & $0.649 \pm 0.081^{\mathrm{a}}$ \\
\hline
\end{tabular}

\section{Effect of tempreatures on moisture loss}

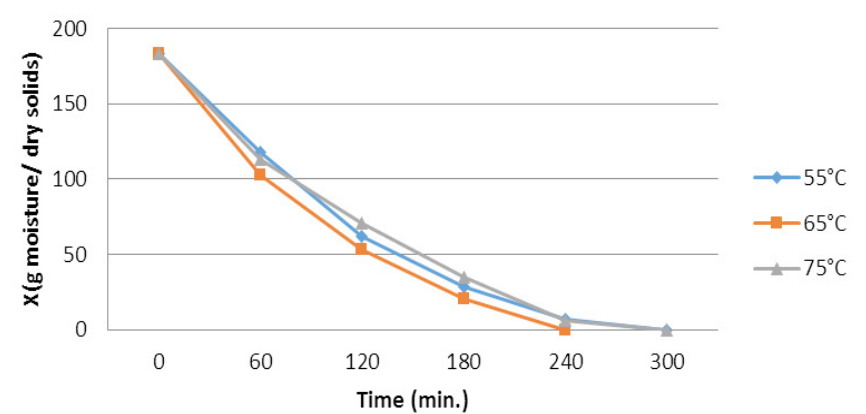

Figure 4: Effect of different temperatures $\left(55^{\circ} \mathrm{C}\right.$, $65^{\circ} \mathrm{C}$ and $75^{\circ} \mathrm{C}$ ) on moisture loss of onion powders developed by $12 \%$ egg albumin as foaming agent.

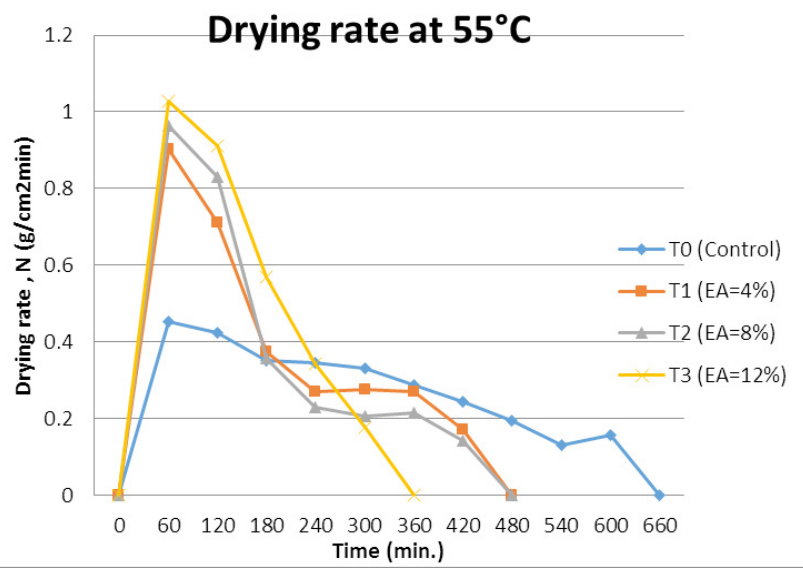

Figure 5: Effect of egg albumin concentration level on drying rate of foam mat dried onion paste at $55^{\circ} \mathrm{C}$.

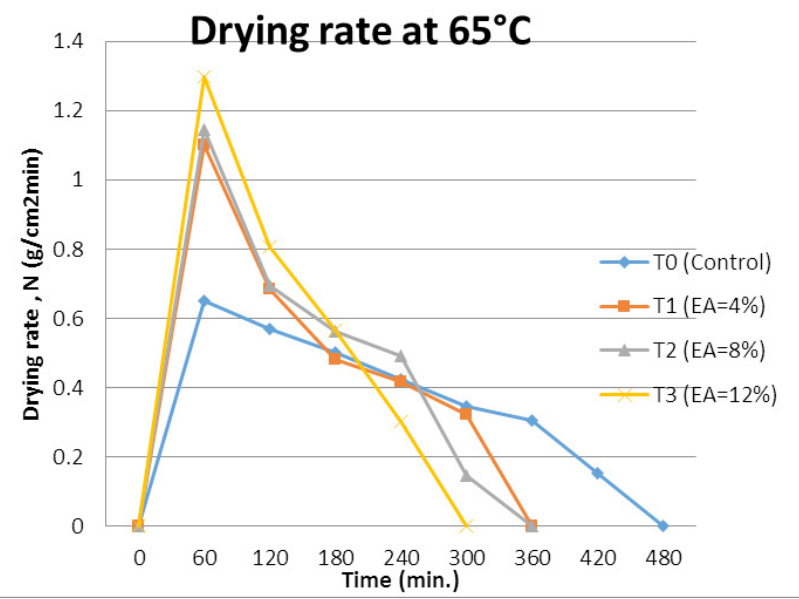

Figure 6: Effect of egg albumin concentration level on drying rate of foam mat dried onion paste at $65^{\circ} \mathrm{C}$.

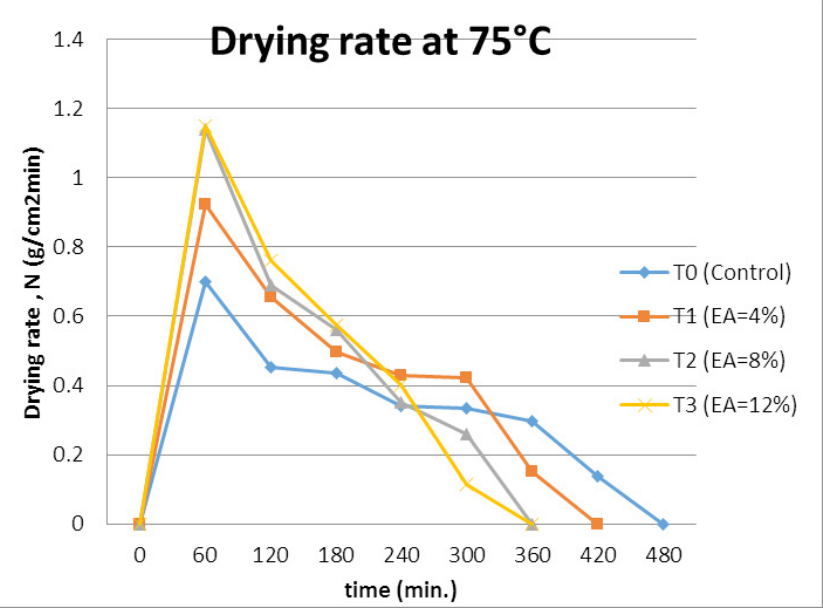

Figure 7: Effect of egg albumin concentration level on drying rate of foam mat dried onion paste at $75^{\circ} \mathrm{C}$.

\section{Conclusions and Recommendations}

Onion powder was prepared by foam-mat drying technique using egg albumin in different concentration as foaming agent. Effect of foaming agent and different drying temperature was studied on moisture loss and drying rate of onion paste. From the results it was found that onion paste which was treated with different concentration of egg albumin as foaming agent was dried in short time as compare to un-foamed onion paste. Moisture loss from foamed onion paste was higher because with foaming treatment surface area for drying was increased which resulted into faster and easy removal of moisture of foamed onion pastes. Moreover, drying rate of onion pastes which were treated with different concentration of egg albumin was higher as compare to un-foamed onion pastes.

\section{Novelty Statement}

The present study will enable readers to understand onion powder by using egg albumin as a foaming agent by foam-mat drying process. 


\section{Author's Contribution}

M. Javed Iqbal and Rizwan Shukat and Wang

Yunyang: Conceived and designed the experiment and performed the experiment.

Qayyum Shehzad and Muhammad Farooq: Data collection and analyzed the data.

Abdul Saboor, Elham Azadfar, Ibrar Ahmad, Shoaib Khan, Kaleem Kakar, Iftikhar Ahmed Solangi and Shabit Ahmad: Wrote original draft, reviewing and editing.

\section{Conflict of interest}

The authors have declared no conflict of interest.

\section{References}

Agnieszka, S., Robert, P., Del, V.L., Silvano, S. and Gianluca, C., 2017. Interactions among genotype, environment and agronomic practices on production and quality of storage onion (Allium cepa L.). A review. Horticultural Science, 44: 21-42. https://doi.org/10.17221/92/2015HORTSCI

AOAC, 2017. Association of official analytical chemists. 2006. Official methods of analysis of AOAC. $18^{\text {th }}$ Ed. AOAC press, Arlington, VA, USA.

Asif, M., 2011. The role of fruits, vegetables, and spices in diabetes. International Journal of Nutrition, Pharmacology, Neurological Diseases, 1: 27. https://doi.org/10.4103/2231-0738.77527

Cardoen, D., Joshi, P., Diels, L., and Pant, D., 2015. Agriculture biomass in India: Part 2. Post-harvest losses, cost and environmental impacts. Resources, Conservation and Recycling, 101: 143-153. https://doi.org/10.1016/j. resconrec.2015.06.002

Chieh,C.,2006. Water chemistry and biochemistry.
Food Biochemistry and Food Processing, 1: 103-

133. https://doi.org/10.1002/9780470277577. ch5

Dehghannya, J., Pourahmad, M., Ghanbarzadeh, B. and Ghaffari, H., 2019. Heat and mass transfer enhancement during foam-mat drying process of lime juice: Impact of convective hot air temperature. International Journal of Thermal Sciences, 135: 30-43. https://doi.org/10.1016/j. ijthermalsci.2018.07.023

Kadam, D.M., Patil, R.T. and Kaushik, P., 2010. Foam mat drying of fruit and vegetable products. In drying of foods, vegetables and fruits volume 1, edited by Jangam, S.V., Law C.L. and Mujumdar, A.S., Published in Singapore.

Kadam, D.M., Patil, R.T. and Kaushik, P., 2011. Foam mat drying of fruit and vegetable products. In drying of foods, vegetables and fruits volume 1, edited by Jangam, S.V., Law, C.L. and Mujumdar, A.S., Published in Singapore.

Keatinge, J.D.H., Yang, R.Y., Hughes, J.D.A., Easdown, W.J. and Holmer, R., 2011. The importance of vegetables in ensuring both food and nutritional security in attainment of the millennium development goals. Food Security, 3: 491-501. https://doi.org/10.1007/s12571011-0150-3

Khokhar, 2012. Production status of major vegetables in Pakistan, their problems and suggestions. Agriculture Corner, pp. 9.

Khokhar, K.M., 2014. Flowering and seed development in onion. A review. Open Access Library Journal, 1: 1. https://doi.org/10.4236/ oalib.1101049

Mishra, R.K., Jaiswal, R.K., Kumar, D., Saabale, P.R. and Singh, A., 2014. Management of major diseases and insect pests of onion and garlic: A comprehensive review. Journal of Plant Breeding and Crop Science, 6: 160-170. https:// doi.org/10.5897/JPBCS2014.0467 